Information for citation:

Ruzakova O. A., Grin E. S. Primenenie tekhnologii Blockchain k sistematizatsii rezul'tatov intellektual'noy deyatel'nosti [Application of Blockchain Technologies in Systematizing the Results of Intellectual Activity]. Vestnik Permskogo Universiteta. Juridicheskie Nauki - Perm University Herald. Juridical Sciences. 2017. Issue 38. Pp. 508-520. (In Russ.). DOI: 10.17072/1995-4190-2017-38-508-520.

UDC 347.2

DOI: 10.17072/1995-4190-2017-38-508-520

\title{
APPLICATION OF BLOCKCHAIN TECHNOLOGIES IN SYSTEMATIZING THE RESULTS OF INTELLECTUAL ACTIVITY
}

\section{O. A. Ruzakova}

Kutafin Moscow State Law University (MSAL)

9, Sadovaya-Kudrinskaya st., Moscow, 125993, Russia

Plekhanov Russian University of Economics

36, Stremyanny pereulok, Moscow, 117997, Russia

ORCID: 0000-0002-7746-399X

ResearcherID: 0-7746-2014

Articles in DB "Scopus" / "Web of Science":

DOI: 10.17072/1995-4190-2017-37-334-349

e-mail: olastep@mail.com

\section{E. S. Grin}

Kutafin Moscow State Law University (MSAL)

9, Sadovaya-Kudrinskaya st., Moscow, 125993, Russia

ORCID: 0000-0002-9630-1742

ResearcherID: F-5817-2016

e-mail: helenkotenko@yandex.ru

Introduction: this article offers a comparative analysis of systematization of the results of intellectual activity in the Russian Federation and abroad. Systems for the registration of creative works in various countries, including Russia, function in different areas. There are registers in libraries and archives, as well as those maintained by organizations for the collective management of rights. In Europe, for example, a register of so-called orphan works (works whose authors are unknown) has been created. At the same time, the fact that a variety of such registers exist often makes commercialization of copyrighted objects quite difficult, especially if the turnover in rights to such objects takes place predominantly on the Internet. This article considers various registration systems for the results of creative work and identifies possibilities for the application of blockchain technologies to the systematization of such results. Purpose: to identify regulatory models for the systematization of the results of creative work in the digital sphere for the purpose of using blockchain technologies for the registration of rights to the results of intellectual activity. Methods: the methodological framework of the research is based on dialectical, formal, functional and other general research methods, as well as special methods used by legal scholars: comparative law research and technical research. Results: the authors have identified and described the existing Russian and foreign mechanisms utilized for the systematization of the results of creative work. Based on the comparative analysis offered herein, the possibilities of using blockchain technologies to systematize the results of intellectual activity have been demonstrated for the purpose of the subsequent creation of a single register of intellectual property. Conclusions: the analysis of systematization of the results of intellectual activity in accordance with Russian law and laws of some foreign countries enables us to conclude that the use of blockchain technologies for the purpose of systematizing the results of intellectual activity makes it possible to store, disseminate and transfer information about copyright objects and

(C) Ruzakova O. A., Grin E. S., 2017 
their rightsholders, their disposal systems, users, etc., and, thusly, can be used instead of the existing databases for intellectual property. The systematization of the results of intellectual activity on the basis of blockchain technologies answers the necessary technical requirements, safety requirements, requirements to decentralization, provides various access levels, and eliminates the need to have a third party to verify the transactions. The use of blockchain technologies would make registration and maintenance of registers by organizations for collective management of copyright and related rights and other organizations much less expensive, and would help to eliminate unnecessary intermediaries in this area.

Keywords: blockchain; intellectual property; copyright; systemization of the results of intellectual activity; copyright registration; Internet systems for the registration of rights; registers of copyrighted items

\title{
Information in Russian
}

\section{ПРИМЕНЕНИЕ ТЕХНОЛОГИИ ВLОСКСНАІN К СИСТЕМАТИЗАЦИИ РЕЗУЛЬТАТОВ ИНТЕЛЛЕКТУАЛЬНОЙ ДЕЯТЕЛЬНОСТИ}

\author{
Исследование выполнено в рамках проведения научно-исследовательских работ РФФИ 20172. \\ № 17-33-00005 по теме «Правовое обеспечение системы учета прав на результаты \\ интеллектуальной деятельности в ичифровой среде: перспективы развития»
}

\section{О. А. Рузакова}

Доктор юридических наук, доцент, профессор кафедры интеллектуальных прав

Московский государственный юридический университет им. О. Е. Кутафина (МГЮА)

125993, Россия, г. Москва, ул. Садовая-Кудринская, 9

профессор кафедры гражданско-правовых дисциплин

Российский экономический университет им. Г. В. Плеханова

117997, Россия, г. Москва, Стремянный пер., 36

ORCID: 0000-0002-7746-399X

ResearcherID: 0-7746-2014

Статьи в БД «Scopus» / «Web of Science»:

DOI: $10.17072 / 1995-4190-2017-37-334-349$

e-mail: olalstep@mail.ru

\section{Е. С. Гринь}

Кандидат юридических наук, доцент кафедры интеллектуальных прав

Московский государственный юридический университет им. О. Е. Кутафина (МГЮА)

125993, Россия, г. Москва, ул. Садовая-Кудринская, 9

ORCID: 0000-0002-9630-1742

ResearcherID: F-5817-2016

e-mail: helenkotenko@yandex.ru

Введение: статья посвящена сравнительному анализу систематизации результатов интеллектуальной деятельности в Российской Федерации и зарубежных странах. Система учета объектов творческого труда в разных странах, в том числе и России, функционирует в различных областях. Так, в библиотеках, архивах реестры ведут организации по коллективному управлению правами. В Европе, например, создан реестр так называемых сиротских произведений - произведений, автор которых неизвестен. Вместе с тем разнообразие таких реестров не всегда позволяет эффективно осуществлять коммерииализацию таких объектов, тем более, если оборот прав осуществляется в сети Интернет. В статье рассматриваются различные системы учета результатов творческого труда, выявляются возможности применения технологий блокчейн применительно к систематизачии таких результатов. Цель: выявить правовые модели систематизачии результатов творческого труда в циирровой среде с иелью возможности использования технологий блокчейн для учета прав на результаты интеллектуальной деятельности. Методы: диалектический, формально-логический, функииональный и другие общенаучные методы исследования, а также специально-юридические методы: сравнительно-правовой и формально-юридический. Результаты: выявлены и охарактеризованы существующие российские и зарубежные механизмы систематизачии резуль- 
татов творческого труда. На основе сравнительного анализа выявлень возможности использования технологий блокчейн для систематизации результатов интеллектуальной деятельности и в последующем с иелью создания единого реестра результатов интеллектуальной деятельности. Выводы: анализ систематизации результатов интеллектуальной собственности по российскому праву и по праву некоторых зарубежных стран позволил сделать вывод: в настоящее время использование технологий блокчейн в иелях систематизации результатов интеллектуальной деятельности может обеспечить хранение, распространение и передачу информации об этих объектах, правообладателях, системе распоряжения ими, пользователях и др. и таким образом позволит заменить существующие базы данных об объектах интеллектуальных прав. Систематизаџия результатов интеллектуальной деятельности на основе технологии блокчейн отвечает признакам современности технологического обеспечения, безопасности, децентрализованности, разным уровням доступности, отсутствие необходимости в наличии третьей стороны для верификациии транзакций. Использование технологий блокчейн при систематизации результатов творческого труда позволит удешевить регистрацию и ведение реестров, осуществляемых организациями по коллективному управлению авторскими и смежными правами, другими организациями, унифицировать эту систему, а также устранить неоправданное посредничество в этой сфере.

Ключевые слова: Blockchain; интеллектуальная собственность; авторские право; систематизация результатов интеллектуальной деятельности; учет авторских прав; системы учета прав в сети Интернет; реестры объектов авторских прав

\section{Introduction}

At present, IT technologies are developing at an extremely rapid pace and inasmuch as they have penetrated almost every sphere of human life, both ordinary people and governments are focusing more and more on the legal regulation of relationships forming on the Internet. Without a doubt, the Internet has made massive amounts of information and various results of intellectual activity accessible to the public. However, both users and copyright owners are faced with many problems and questions with respect to the legal regulation of relationships arising in connection with the circulation of the rights to results of intellectual activity in the digital world.

When speaking at the VI International Law Forum in St. Petersburg, Dmitry Medvedev (Chairman of the Government of the Russian Federation) noted that, at present, in the digital sphere "it is very hard and sometimes even impossible to identify your legal counterparty, and, as a result, there is a problem of trusting the legal form in this case. Accordingly, specific skills are required for the use of legal instruments, as they must keep up with the rapid changes in communication technologies"1. Medvedev also noted that "the absence of a balance of the interests of rightsholders and users is creating

\footnotetext{
${ }^{1}$ Website of the Government of the Russian Federation [Electronic resource] URL: http:/government.ru/news/23074/ (accessed on: 20.05.2017).
}

an obstacle for the free exchange of scientific information and hinders the development of hi-tech business. Therefore, we need to find a balance between the new technological environment and the traditional values of copyright laws" 2 .

The issues raised by Dmitry Medvedev concerning the use of blockchain technologies in law were discussed at length by the participants in the VI International Law Forum: "The conflict between rightsholders and users is escalating... the absence of a balance of the interests of rightsholders and users is creating an obstacle for the free exchange of scientific information, hindering the development of hi-tech business and forcing people to break the law on a regular basis. Therefore, we need to find a balance between the new technological environment and the traditional values of copyright laws. In this case, the government must act as an arbiter, and determine whose interests must be protected to ensure stable economic and social growth"3. It is proposed that special consideration must be given to blockchain technology, otherwise known as 'smart contract', when property transfer transactions, for example, or the verification of property rights are concluded and executed automatically, and when not people, but electronic de-

\footnotetext{
${ }^{2}$ Ibid.

${ }^{3}$ Website of the Government of the Russian Federation [Electronic resource] URL: http://government.ru/news/23074/ (accessed on: 20.05.2017).
} 
vices, interact with each other online for these purposes (for example data exchange or actions on behalf of an owner, etc.).

Blockchain technologies may be used to create a single register of the results of intellectual activity. The various possibilities offered by such technologies are contained in some foreign studies.

\section{Systematization of Orphan Works, Foreign Experience}

The Directive 2012/28/EU of the European Parliament and of the Council of 25 October 2012 on certain permitted uses of orphan works (works whose author or rightsholder has not been identified) states that a single database of works whose authors cannot be identified is to be created. According to clause 2 of the Directive, the need to promote free movement of knowledge and innovation in the internal market is an important component of the Europe 2020 Strategy, as is set out in the Communication from the Commission entitled 'Europe 2020: A strategy for smart, sustainable and inclusive growth', which includes as one of its flagship initiatives the development of a Digital Agenda for Europe. A digital agenda for Europe is very much needed, since EU libraries, educational establishments and museums, as well as the collections of archives of film or audio heritage institutions and public service broadcasting organizations are currently digitizing their material in order to create European digital libraries. This helps to preserve and disseminate European cultural heritage and is required to create European digital libraries (for example, the EU digital library Europeana, which provides access to scanned pages of books reflecting the various aspects of the European culture).

Such online libraries help to improve electronic searches and provide scientists and researchers with new sources of knowledge.

According to Article 3 of the Directive, for the purposes of establishing whether a work or phonogram is an orphan work, a diligent search for a rightsholder must be carried out in good faith with respect to each work.

The indicated Directive applies to:

- works published in the form of books, journals, newspapers, magazines or other writings con- tained in the collections of publicly accessible libraries, educational establishments or museums as well as in the collections of archives or of film or audio heritage institutions;

- cinematographic or audiovisual works and phonograms contained in the collections of publicly accessible libraries, educational establishments or museums as well as in the collections of archives or of film or audio heritage institutions;

- cinematographic or audiovisual works and phonograms produced by publicservice broadcasting organizations up to and including 31 December 2002 and contained in their archives [16].

The document covers the results of intellectual activity which are protected by copyright or related rights and which have first been published in a Member State of the EU or, in the absence of publication, first broadcast in a Member State [6].

The Directive also applies to works and phonograms referred to above which have never been published or broadcast but which have been made publicly accessible by the indicated organizations (publicly accessible libraries, educational establishments or museums as well as archives and film or audio heritage institutions) with the consent of the rightsholders, provided that it is reasonable to assume that the rightsholders would not oppose the uses referred to in Article 6 of the Directive (permitted use of orphan works). Member States may limit the application of this provision of the Directive to works and phonograms which have been deposited with those organizations before 29 October 2014. The Directive also applies to works and other protected subject matter that are embedded or incorporated in, or constitute an integral part of the works or phonograms referred to above.

The Annex to the Directive provides a list of registers' sources that are appropriate for each category of works or phonograms which shall be determined by each Member State, in consultation with rightsholders and users [20]. For example, for published books - legal deposit, library catalogues and authority files maintained by libraries and other institutions; the publishers' and authors' associations in the respective country; existing databases and registries, WATCH (Writers, Artists and their Copyright Holders), the ISBN (International Stand- 
ard Book Number) and databases listing books in print; databases of the relevant collecting societies, in particular reproduction rights organizations; sources that integrate multiple databases and registries, including VIAF (Virtual International Authority Files [25]) and ARROW (Accessible Registries of Rights Information and Orphan Works [18]), and others.

For newspapers, magazines, journals and periodicals: the ISSN (International Standard Serial Number) for periodical publications; indexes and catalogues from library holdings and collections; legal deposit; the publishers' associations and the authors' and journalists' associations in the respective country; databases of the relevant collecting societies, including reproduction rights organizations;

Separate databases and registers are created for visual works, including fine art, photography, illustration, design, architecture, sketches of those, and other such works that are contained in books, journals, newspapers and magazines or other sources (in addition to those listed above, for example, databases of the relevant collecting societies, in particular for visual arts, and including reproduction rights organizations).

For audiovisual works and phonograms: legal deposit; producers' associations in the respective country; databases of film or audio heritage institutions and national libraries; databases with the relevant standards and identifiers, such as ISAN (International Standard Audiovisual Number) for audiovisual material, ISWC (International Standard Music Work Code) for musical works and ISRC (International Standard Recording Code) for phonograms and others.

\section{Registration of Copyright and Related Rights in Russia}

Considering that intellectual activity results (intellectual property) comprise a variety of issues [5, p. 57-74], Russia has also created and maintains various copyright and related rights registers $[1, \mathrm{pp}$. 29-33, 8, pp. 286-287].
The main purpose of the development of the Russian library system until 2020 is the creation of a single technology for public information and library services, wherein each citizen can gain free access (local or remote) to all documents stored in any Russian library, provided that the requirements of the current laws are observed .

In Russia, for example, a consolidated catalogue of Russian libraries has been created. It is a centralized consolidated electronic catalogue intended for professional information and bibliography servicing and navigation through the collections of the participants in the catalogue. It contains bibliographic records of more than 6 million items and almost 20 million copies of publications.

This system of corporate cataloguing LIBNET is a bibliographic database created by LIBNET Center in the process of corporate classification with the participation of national, central regional, industry, university and municipal libraries with the methodological support of Russian national libraries - the Russian State Library, Russian National Library and Boris Yeltsin Presidential Library.

This database contains documents from the holdings of more than 500 major libraries across the country. Once users have searched for and found the item they are looking for, they can access the catalogue of the library - holder of the required copy - remotely, and order a specific service in relation to the found document, for example make a preliminary book order, submit a request for electronic delivery or copies of certain pages, gain access to a digital copy and other things.

The catalogue is publicly available online. Users can conduct free searches in the catalogue using specific search criteria and keywords and find the required edition, obtain information about the publication and find out which libraries have the required copy. Users can also download information from the database for a fee.

In addition, the Russian System for Information Support of Cultural Activities (created in 1995 for the purpose of rendering information sup- 
port to the development and implementation of the Russian cultural policy and to create a single information environment for culture and arts) is an open system which unites libraries and museums, research and scientific institutions, creative centers, and other organizations engaged in information activities in the sphere of culture.

This system has the following online resources:

- a consolidated catalogue of publications and unpublished documents from Russian regional libraries. This is a bibliographic database of printed and electronic publications and unpublished documents created by the libraries of the Russian constituencies starting from 2010. The consolidated catalogue contains bibliographic records, information about the storage location and weblinks to digital copies of publications;

- a guide to Internet resources. The guide includes several sections ('General Matters of Culture', 'Culture in Faces', 'Museums and Cultural Heritage', 'Library Holdings', 'Art', 'Literary Life of the Russian Regions') and an A-Z library directory;

- a library in the era of change - an electronic information publication of the Russian State Library devoted to current issues pertaining to the development of libraries and information;

- librarianship and bibliography - a database of references and bibliographic information about national and foreign printed publications since 2010.

The website of the Russian System for Information Support of Cultural Activities also contains an archive comprised of other topic-based resources, for example, a catalogue of references and bibliographic resources for culture, arts, etc.

The catalogues are open and accessible to the public. Users can conduct searches in the catalogue using specific criteria and keywords and find the required materials, and obtain reference information about them or the materials themselves.

The Russian State Library (RSL) maintains the Single Electronic Catalogue of the RSL, which in- cludes bibliographic records for all types of documents stored in the RSL, such as articles published in Russian and other languages on different media and in different periods of time. The catalogue functions in two modes: public online access (for files that can be opened and downloaded) and restricted access (users can obtain only reference information with respect to certain works).

The Russian State Library accepts nonpublished results of intellectual activity into deposit and issues certificates of deposit to the authors.

According to the RSL rules, having signed a deposit application, the author, on a gratis basis, provides the library with a non-exclusive right to publish a digital copy of the deposited work in the fund of deposited works with the possibility of subsequent publication in the electronic library of the Russian State Library for the purpose of providing the readers with open access to the work. Once the work is deposited, the author is issued with a certificate of deposit of the intellectual activity results .

The Russian Book Chamber maintains bibliographic and statistical records of all printed publications released in the Russian Federation.

Registers are also maintained by organizations for the collective management of intellectual property.

The Russian Author Society (RAO) maintains the following registers:

- works of Russian rightsholders;

- works of foreign rightsholders;

- deposited works.

The registers of the RAO contain information about the rightsholders, works, and rights managed by the RAO.

The RAO accepts unpublished works into deposit. The following can be deposited in the RAO with the issuance of the relevant Certificate: manuscripts containing short stories, novellas, novels, poems, text books, study manuals, plays, articles, etc.; manuscripts containing screenplays for documentaries, full-length feature films, commercials, clips, etc.; manuscripts containing literary transla- 
tions; author's descriptions of games, quizzes, lotteries; architectural projects; descriptions and scripts of festivals and contests; works of visual arts, including sketches of trademarks, emblems etc.

The Russian Union of Rightsholders (RUR) maintains registers of the following: works, phonograms, audiovisual products, as well as their rightsholders . Registers of the results of intellectual activities are maintained by other organizations for the collective management of rights: the Russian Intellectual Property Organization maintains a register of phonograms; the register of the NonProfit Partnership for the Protection and Management of Rights to Art Products UPRAVIS contains information about works of fine arts the rights to which are managed collectively both in Russia and abroad.

Registers are also maintained by commercial organizations, for example, the Unified Depository of the Results of Intellectual Activity (register of works of design, literature, science, art, etc.); Single Register of Authors and Certified Works of Art ARTREEST (the register is almost exclusively devoted to works of visual arts); Database of the Results of Intellectual Activities for Business RIDBusiness (accepts scientific works into deposit); COPYTRUST System (users can deposit their works independently in electronic form by uploading an electronic file through the "personal office" space on the website), etc.

Blockchain Technologies: Foreign Experience

Blockchain technologies are widely considered as a means to protect the results of intellectual activity, especially copyright and related rights.

Blockchain is a distributed database that is used to maintain a continuously growing list of records, called blocks, which is used by the cryptocurrency Bitcoin (a banking technology for the circulation of Bitcoin where payments are made without any intermediaries) .
In the USA, in the states of Vermont and Arizona, blockchain technologies are used for digital transactions. Thus, according to article 5 ('blockchain technology') of the Amending section 447003 of the Arizona revised Statutes and Amending title 44, chapter 26 of the Arizona revised statutes $[19,22,13]$, blockchain technology is defined as a distributed ledger technology that uses a distributed, decentralized, shared and replicated ledger, which may be private or public, permissioned or permissionless, or driven by tokenized crypto economics or tokenless. The data on the ledger is protected with cryptography (clause 1E article 5).

Tokenization is the process of replacing sensitive data with unique identification symbols (tokens) that retain all the essential information about the data without compromising its security . Tokens are designed to serve as electronic ID (for example, to be used by clients gaining access to their banking accounts), and they can be used both instead of a password or together with a password. A token is essentially an electronic access key .

The indicated law makes special provisions for the so-called 'smart contracts'. According to clause 2 article 5 of the law, a smart contract is an eventdriven program that runs on a distributed, decentralized, shared and replicated ledger and that can take custody over and instruct transfer of assets on that ledger. According to the document, such smart contracts can be used for commercial transactions.

They key property of blockchain is the anonymity of members of the network, stability of operation and absence of central control. Another important thing is that all transactions are automated. As noted above, blockchain technology serves as foundation for cryptocurrency, for example, Bitcoin (from English bit and coin) - a peer-to-peer payment system which uses Bitcoin cryptocurrency and transfer protocol.

Thanks to blockchain, cryptocurrencies (digital assets) do not need a bank to act as an interme- 
diary; using the same logic, many industries can get rid of the middle man .

As noted by Paolo Tasca (Executive Director of the Centre for Blockchain Technologies (UCL CBT) at University College, London): "Blockchain decentralizes decision making. Each peer, each community member, can interact with others and partake in this information exchange".

During the same session, Alexander Saveliev (legal consultant, IBM Eastern Europe/Asia) noted that blockchain "fits copyright protection purposes perfectly". Firstly, ownership is documented and timestamped. Secondly, the moment when permission to use a specific object was granted is also documented, thus generating a copyright register. Additionally, a timestamp is made each time a permission is granted to use objects of certain categories, e.g. a song or a software copy, etc. Moreover, according to the speaker, "if we put a smart contract on top of blockchain, it opens amazing opportunities - process automation, all the way from when the contract is entered up until the enforcement stage. In fact, it would be possible to obtain any free license, which would be as easy to use on the Internet as Creative Commons. It could be lucrative too. One could earn money, in bitcoins, for instance".

\section{Blockchain in the System of Intellectual Property Protection}

Blockchain is based on a distributed ledger system without centralized data storage. All transactions are processed and verified by the users of the ledger.

There are different types of blockchain [24].

1. Public blockchain - a blockchain with no restrictions to the use of separate blocks (despite the fact that the data in the blocks may be encrypted) or to the submission of transactions to be included in the blockchain.

A permissionless blockchain is a type of a public blockchain where users can create blocks and make transactions without any restrictions [10].
2. A private blockchain or a consortium blockchain platform is the opposite of a public blockchain. Here, access to data and transactions are restricted to a specific number of users.

A private blockchain is less expensive and is faster than a public blockchain. However, a public blockchain is still more effective and is faster than the systems that are currently in use [24].

3. A permissioned blockchain is not always a type of a private blockchain. In permissioned blockchains, blockchain building is restricted to a set of known entities. The term "permissioned" reflects the fact that the entities building the blockchain may introduce policies to arbitrarily censor transactions, therefore potentially restricting the blockchain use by end users and application. A permissioned blockchain may have various levels of openness, specifically:

"1. The transactions in the blockchain can be read with some restrictions (for example, the client may have access only to those transactions that concern them); 2. Transactions can be offered for inclusion in the blockchain; 3. New transaction blocks can be created and added to the blockchain".

When it comes to examining different types of blockchains, it is not a matter of which is "better" public, private, permissioned or permissionless. According to Devon Allaby, for many enterprise use cases, a permissioned Blockchain can meet business requirements that are simply impossible to meet with a permissionless Blockchain. In contrast, some of the incredible use cases for industry disruption, disintermediation and social infrastructure by nature require an open, public Blockchain. Accordingly, a presumption to evaluate either in the absence of a well-defined use case is a fruitless exercise [10].

At present, blockchains are mostly used for financial transactions; however, blockchain technologies can be employed to register documents and to protect them from changes. When bitcoin first came onto the scene, the enterprise community quickly understood the potential of its underlying blockchain technology. However, it also quickly saw the 
limits in the business environment of the kind of public, permissionless distributed ledgers the bitcoin blockchain represented. Such limitations related to speed, security, privacy, cost, lack of programmability in the original bitcoin blockchain. The list goes on. Many of these issues are a result of the functionalities needed to make a public blockchain viable (for example, the consensus mechanisms that prohibit cheating) [12]. Such functionalities must be taken into account when copyright registers are created.

Blockchain technology is still in its early stages. There is no consensus whether Satoshi Nakamoto - an unknown programmer, or a group of programmers who developed Bitcoin- was indeed the first to create the first version of the software that implemented the blockchain protocol . Bitcoin - a fully decentralized digital currency - was first described in an article published on October 31, 2008 [21].

Blockchain technologies and their implementation are being studied by many specialists and researchers worldwide, and the Russian Federation must not fall behind.

Blockchain technologies do not have to be limited to the financial sphere, but can be used to create distributed ledgers of rights, including real estate ledgers, transportation ledgers, by notaries, for voting purposes, document circulation, information exchange, smart contract services and security [2].

Participants in blockchain systems will have access to the information about when a certain "block" appeared on the ledger and will enjoy an exclusive right to the block, provided that such information will be entered on the ledgers. Each participant in a private blockchain or any interested party will be able to obtain identical information which will be received without the participation of the central depository.

It will be rather easy for a new user to join an existing network in order to obtain full access to all required information. Any changes in the procedure and the results in a distributed ledger are recorded, their copies are disseminated to all participants and may be easily verified [9].

There are many different potential applications for such ledgers, as they can be used not only in the area of financial assets and securities, but in intellectual property as well. In the latter case, a digital ledger of copyrighted items can be very useful, as it will facilitate free trade in such items in the secondary market (for example, sale of "used" software, phonograms and films in digital form, etc.) [9]. Blockchain technologies are already being used in certain areas of intellectual property protection, for example, in the fashion industry, where it is used for the registration and identification of IP rights, control and monitoring of the use of exclusive rights, evidence of use, assignment and change of title information and licensing agreements through smart contracts, payments to the rightsholder for use, identification of counterfeits and parallel imports [11].

The system for the registration of patented items, selection inventions, trademarks, protected appellations of origin, integrated circuit topographies [7, pp. 24-25; 3, p. 88; 11] does not really require the use of a distributed ledger, as it is operated at a very high level - the Federal Service for Intellectual Property - a government executive body.

The main difference between systems for the registration of patent rights or brands $[4 ; 15 ; 14, \mathrm{pp}$. 269-279.] and those for the registration of copyright and related rights is in the fact that the latter do not affect the occurrence of intellectual rights to works or performances or other objects of related rights, which, nevertheless, does not diminish the importance of the need to create a well-functioning system for the registration and documentation of such rights both in Russia and abroad [17].

In addition, verification is required when registering patented objects or brands. Such verification cannot always be performed by technology, and often, an expert is needed to analyze the criteria of protectability. 


\section{Results of the study}

Potential uses of blockchain are especially relevant for copyright and related rights as they make the information about the rightsholder accessible to potential users and can be used for such mechanisms as, for example, open licenses. Provided that appropriate software is in place, we believe that a method of legal non-gratis downloading of a published work (object of related right) can be worked out; provisions can be made for other uses of protected objects with the rightsholder's consent, including organization of an exchange in electronic files similar to Bitcoin exchange.

At the same time, considering that this technology and its functionalities are quite novel, appropriate provisions, similar to those made in relation to the use of copyright and related rights objects on the Internet, must be drafted into the law with regard to the new uses of protected objects. According to the Federal Law No. 72-FZ On Amendments to the Law of the Russian Federation on Copyright and Related Rights ${ }^{1}$, the definition of exclusive right was expanded whereby a work can be communicated in such a way as to enable any person to obtain access to it interactively from any location and at any time at their own discretion (the right to communicate for public notice).

One of the problems of using blockchain technologies for the purpose of maintaining registers of rightsholders is the problem of IP protection. This system does not automatically ensure such protection. A mechanism which would make it impossible to create unprotected copies infringing on the rights of authors and other rightsholders needs to be created.

A permissioned blockchain (where the publication of information and processing of transactions needs to be validated) seems to be optimal for the creation of copyright and related rights registers, where the information entries and the relevant transactions will be handled/validated by entities

${ }^{1}$ Corpus of Legislation of the Russian Federation. 2004, № 30 , p. 3090 performing optional registration of copyright and related rights. The access to a permissioned blockchain must not be restricted to the indicated entities; such access must have elements of openness, which is very important for users, but ensure that exclusive rights remain protected. A combination of several blockchains is possible, when elements of permissionless and permissioned blockchains will be used. Security can be ensured by merged mining - a technique that allows for the use of the same proof of work mining equipment to secure more than one blockchain, which is already being used in the financial sphere. One of major advantages of blockchains, compared to other distributed databases, is the integration of data processing, consistency and security into an algorithmically enforced blockchain protocol, which removes the human factor from the equation ${ }^{2}$.

Using blockchain as an IP registry may help give clarity to copyright authors, owners and users. By registering their works to a blockchain, authors could end up with tamper-proof evidence of ownership. This is because a blockchain transaction is immutable, so once a work has been registered to a blockchain, that information cannot ever be lost or changed. In theory, third parties could use the blockchain to see the complete chain of ownership of a work, including any licenses, sub-licenses and assignments. With blockchain platforms such as Blockai and Ascribe, once a work is registered and verified, authors can search across a whole host of different sources simultaneously to see who is using their work, thereby making it easier to identify and stop infringements and put in place licenses for any use they wish to authorize. Registration provides authors with an electronic certificate of authentici-

\footnotetext{
${ }^{2}$ Overview of public and private blockchains by BitFury. Public and private blockchains. Part 1: permissioned blockchains. White Paper (in Russ.) BitFury Group in cooperation with Jeff Garzik (jeff@bloq.com) 22 October 2015 (version 1.0-ru). [Electronic resource] URL: http://forklog.com/issledovanie-bitfury-sochetanieotkrytyh-i-eksklyuzivnyh-blokchejnov-effektivnyj-putrazvitiya-kriptotehnologij/28.05.2017 (accessed on: 30.05.2017).
} 
ty, which makes it possible for third parties to identify the author and for authors and other rightsholders - to detect infringement. According to Nathan Lands, CEO of Blockai: "The blockchain is the perfect solution for providing proof of creation. It is a permanent immutable record. Meaning, once the record is there, it is there forever and will never change." One result of this is that orphan works could become a thing of the past, as there will always be an unalterable record of copyright authorship [23].

\section{Conclusions}

Creating a blockchain-based IP register will make it possible to use content legally. Nevertheless, before such a register is introduced, it is necessary to develop criteria for its creation, ensure that proper technical testing is conducted and that a balance of interests of rightsholders and users is maintained. Such registers are especially relevant now when millions of people are using social media platforms (Instagram, VKontakte, Facebook, Odnoklassniki) to exchange various types of files. Accordingly, it is necessary to carefully consider the creation of a blockchain-based register where users must have the opportunity to legally use intellectual property and rightsholders - to get paid for such use.

Blockchain-based copyright and related rights registers answer the necessary technical requirements, safety requirements, requirements to decentralization, various access levels, absence of a need to have a third party to verify the transactions. The blockchain as a system of intellectual property registers can ensure storage, dissemination and transfer of information about intellectual property, the rightsholders, permitted uses and users, and, therefore, could replace the existing intellectual property databases.

The use of blockchain technologies to create copyright and related rights registers maintained by organizations for collective management of copyright and related rights and other organizations is much less expensive, and will help to eliminate unnecessary intermediaries in this area.
In addition, with blockchain technologies authors and other rightsholders can track the path of the object belonging to them. This is what makes blockchain different from using works and other objects on the Internet. It is important for the purpose of identifying infringements of exclusive rights and for the circulation of rights.

\section{References}

1. Avtorskie i smezhnye s nimi prava. Postateynyy kommentariy glav 70 i 71 Grazhdanskogo kodeksa Rossiyskoy Federatsii; pod red. P. V. Krasheninnikova [Copyright and Related Rights. Article-by-article Commentary on Chapters 70 and 71 of the Civil Code of the Russian Federation; ed. by P. V. Krasheninnikov]. Moscow, 2010. 480 p. (In Russ.).

2. Bulgakov I. T. Pravovye voprosy ispol'zovaniya tekhnologii blokcheyn [Legal Issues of the Use of Blockchain]. Zakon - ZAKON. 2016. Issue 12. Pp. 80-88. (In Russ.).

3. Novoselova L. A., Grin' E. S., Vorozhevich A.S. $K$ voprosu ob uchete prav na olimpiyskuyu simvoliku [The issue of rights for Olympic symbols]. Teoriya i praktika fizicheskoy kul'tury - Teoriya i praktika fizicheskoy kultury. 2017. Issue 6. P. 88. (In Russ.)

4. Patentnoe pravo. Postateynyy kommentariy glavy 72 Grazhdanskogo kodeksa Rossiyskoy Federatsii; pod red. P. V. Krasheninnikova [Patent Law. Article-by-article Commentary on Chapter 72 of the Civil Code of the Russian Federation; ed. by P. V. Krasheninnikov]. 2010. 464 p. (In Russ.)

5. Postateynyy kommentariy $k$ Grazhdanskomu kodeksu Rossiskoy Federatsii, chasti chetvertoy; pod red. P. V. Krasheninnikova [Articleby-article Commentary on the Part Four of the Civil Code of the Russian Federation; ed. by P. V. Krasheninnikov]. 2011. 926 p. (In Russ.).

6. Pravo intellektual'noy sobstvennosti: uchebnik; pod red. L. A. Novoselovoy [Intellectual Property Right: Textbook; ed. by L. A. Novoselova]. Vol. 1. Obschie polozheniya [General provisions]. Moscow, 2017. 511 p. (In Russ.).

7. Ruzakova O.A. Problemy gosudarstvennoy registratsii v grazhdanskom prave [Problems of State Registration in the Civil Law]. Zakonodatel'stvo - Legislation. 2002. Issue 2. Pp. 2328. (In Russ.).

8. Ruzakova O. A., Ruzakov A. B. Problemy unifikatsii zakonodatel'stva stran ES v oblasti avtorskogo prava [Problems of Unification of Legislation of the EU Countries in the Field of 
Copyright]. Patenty $i$ licenzii. Intellektual'nye prava - Patents and Licenses. Intellectual Rights. 2015. Issue 1. Pp. 70-75. (In Russ.).

9. Savel'ev A. I. Dogovornoe pravo 2.0: «umnye» kontrakty kak nachalo konca klassicheskogo dogovornogo prava [Contract Law 2.0: "Smart Contracts" and the Beginning of the End of the Classic Contract Law]. Vestnik grazhdanskogo prava - Civil Law Review. 2016. Issue 3. Pp. 32-60. (In Russ.).

10. Allaby D. Business Designer at Fjord Australia. The Trust Trade-Off: Permissioned vs Permissionless Blockchains. Available at: https:// www.fjordnet.com/conversations/the-trust-tradeoff-permissioned-vs-permissionless-blockchains/ (accessed 30.05.2017). (In Eng.).

11. Burstall R., Clark B. Blockchain, IP and the Fashion Industry. Managing Intellectual Property. Available at: http://www.managingip.com/ Article/3667444/Blockchain-IP-and-the-fashionindustry.html (accessed 30.05.2017). (In Eng.).

12. Bussmann O. BankThink. A Public or Private Blockchain? New Ethereum Project Could Mean Both. March 01 2017, 9:30 am EST. Available at: https://www.americanbanker.com/opinion/apublic-or-private-blockchain-new-ethereum-project-could-mean-both (accessed 30.05.2017). (In Eng.).

13. Grewal-Carr V., Marshall S. Blockchain: Enigma. Paradox. Opportunity (Deloitte). Available at: https://www2.deloitte.com/content/dam/Deloitte/uk/Documents/Innovation/de loitte-uk-blockchainfull-report.pdf (accessed 30.05.2017). (In Eng.).

14. Grin E.S., Grin O.S. An Open License Contract in Intellectual Property: Russian Experience. Kutafin University Law Review. 2017. Vol. 4. Issue 1. Pp. 269-279. (In Eng.).

15. Grin E. S. Intellectual Property in Sports: Trademark Use Features. Theory and Practice of Physical Culture. 2016. Issue 7. P. 30. (In Eng.).

16. Herther N. K. Libraries, Orphan Works, and the Future of Copyright. Available at: http://newsbreaks.infotoday.com/NewsBreaks/LibrariesOrphan-Works-and-the-Future-of-Copyright113842.asp (accessed 30.05.2017). (In Eng.).

17. Khatri B. Resurrecting Copyright Formalities: No 'Deadly' Human Rights Implications. LLLM Research Paper. Laws 532: Human Rights and Intellectual Property. Victoria University of Wellington, 2016. 25 p. Available at: http://researcharchive.vuw.ac.nz/bitstream/handle/10063/5226/paper.pdf?sequence $=1$ (accessed 30.05.2017). (In Eng.).

18. Mark Bide. Arrow - Steps Towards Resolving the 'Orphan Works Problem'. Serials. March 2010. Issue 23(1). Available at: http://www.edi-
teur.org/files/Collaborations/Publications/Serial s\%20March\%202010\%20-\%20Mark\%20Bide $\% 20-\% 20$ ARROW\%20-\%20steps\%20towards \%20resolving\%20the\%20orphan\%20works $\% 2$ 0problem.pdf (accessed 01.06.2017). (In Eng.).

19. Meadows I., Crawford S., Piesse D. (EY). Blockchain Technology as a Platform for Digitization. Implications for the Insurance Industry. Available at: http://www.ey.com/Publication/vwLUAssets/EY-blockchain-technology-as-a-platform-for-digitization/\%24FILE/EY -blockchain-technology-as-a-platform-for-digitization.pdf (accessed 30.05.2017). (In Eng.).

20. Mendis D. Orphan Works. Available at: http:// www.Copyrightuser.org/topics/orphan-works/ (accessed 30.05.2017). (In Eng.).

21. Satoshi Nakamoto. Bitcoin: a Peer-to-Peer Electronic Cash System. Available at: www.bitcoin.org//https://bitcoin.org/bitcoin.pdf (accessed 30.05.2017). (In Eng.).

22. Silver J. Blockchain or the Chaingang? Challenges, Opportunities and Hype: the Music Industry and Blockchain Technologies. Available at: http://www.create.ac.uk/publications/blockchain-or-the-chaingang-challenges-opportunities-and-hype-the-music-industry-and-blockchaintechnologies/ (accessed 30.05.2017). (In Eng.)

23. Shinner S. Blockchain Technology and IP. Available at: https://www.taylorwessing.com/download/article-blockchain-technologyand-ip.html (accessed 30.05.2017). (In Eng.).

24. Thompson $C$. The Difference between a Private, Public \& Consortium Blockchain. A Simple Explanation for Dummies. Available at: http:// www.blockchaindailynews.com/The-differencebetween-a-Private-Public-Consortium-Blockchain_a24681.html (accessed 30.05.2017). (In Eng.).

25. Toves J. A., Hickey T. B. Parsing and Matching Dates in VIAF. Available at: http://journal.code4lib.org/articles/9607 (accessed 01.06.2017). (In Eng.).

\section{References in Russian}

1. Авторские и смежные с ними права. Постатейный комментарий глав 70 и 71 Гражданского кодекса Российской Федерации / под ред. П. В. Крашенинникова. М.: Статут, 2010. $480 \mathrm{c}$.

2. Булгаков И. Т. Правовые вопросы использования технологии блокчейн // Закон. 2016. № 12. C. $80-88$.

3. Новоселова Л.А., Гринь Е. С., Ворожевич $A$. C. К вопросу об учете прав на олимпийскую символику // Теория и практика физической культуры. 2017. № 6. С. 88. 
4. Патентное право. Постатейный комментарий главы 72 Гражданского кодекса Российской Федерации / под ред. П. В. Крашенинникова. М.: Статут, 2010. 464 с.

5. Постатейный комментарий к Гражданскому кодексу Российской Федерации, части четвертой / под ред. П. В. Крашенинникова. М.: Статут, 2011. 926 с.

6. Право интеллектуальной собственности: учебник. Т. 1: Общие положения / под ред. Л. А. Новоселовой. М.: Статут, 2017. 511 с.

7. Рузакова О.А. Проблемы государственной регистрации в гражданском праве // Законодательство. 2002. № 2. С. 23-28.

8. Рузакова О.А., Рузаков А. Б. Проблемы унификации законодательства стран ЕС в области авторского права // Патенты и лицензии. Интеллектуальные права. 2015. № 1. C. $70-75$.

9. Савельев А. И. Договорное право 2.0: «умные» контракты как начало конца классического договорного права // Вестник гражданского права. 2016. № 3. С. 32-60.

10. Allaby D. Business Designer at Fjord Australia. The Trust Trade-Off: Permissioned vs Permissionless Blockchains. URL: https://www.fjordnet.com/conversations/the-trust-trade-off-permissioned-vs-permissionless-blockchains/ (дата обращения: 30.05.2017).

11. Burstall R., Clark B. Blockchain, IP and the fashion industry. Managing Intellectual Property. URL: http://www.managingip.com/Article/ 3667444/Blockchain-IP-and-the-fashion-industry.html (дата обращения: 30.05.2017).

12. Bussmann O. BankThink A public or private blockchain? New Ethereum project could mean both. URL: https://www.americanbanker.com/opinion/a-public-or-private-blockchain-new-ethereum-project-could-mean-both (дата обращения: 30.05.2017).

13. Grewal-Carr V., Marshall S. Blockchain. Enigma. Paradox. Opportunity (Deloitte). URL: https://www2.deloitte.com/content/dam/ Deloitte/uk/Documents/Innovation/deloitte-ukblockchainfull-report.pdf (дата обращения: 30.05.2017).

14. Grin E. S., Grin O. S. An open license contract in intellectual property: Russian experience // Kutafin University Law Review. 2017. Vol. 4, issue 1. Pp. 269-279.

15. Grin E.S. Intellectual property in sports: trademark use features // Theory and Practice of Physical Culture. 2016. Issue 7. P. 30.

16. Herther N. K. Libraries, Orphan Works, and the Future of Copyright. URL: http://newsbreaks.
infotoday.com/NewsBreaks/Libraries-OrphanWorks-and-the-Future-of-Copyright-113842.asp (дата обращения: 30.05.2017).

17. Khatri B. Resurrecting Copyright Formalities: No 'Deadly' Human Rights Implications. Llm Research Paper. Laws 532: Human Rights and Intellectual Property. Victiria University of Wellington, 2016. 25 p. URL: http://researcharchive. vuw.ac.nz/bitstream/handle/10063/5226/paper. pdf? sequence=1 (дата обращения: 30.05.2017).

18. Mark bide arrow - steps towards resolving the 'orphan works problem'// Serials. March 2010. Issue 23(1). URL: http://www.editeur.org/files/ Collaborations/Publications/Serials\%20March\% 202010\%20-\%20Mark\%20Bide\%20-\%20ARROW\%20-\%20steps\%20towards\%20resolving $\% 20$ the $\% 20$ orphan $\% 20$ works $\% 20$ problem.pdf (дата обращения: 01.06.2017).

19. Meadows I., Crawford S., Piesse D. (EY). Blockchain Technology as a Platform for Digitization Implications for the Insurance Industry. URL: http://www.ey.com/Publication/vwLU Assets/EY-blockchain-technology-as-aplatformfor-digitization/\%24FILE/EY-blockchain-technology-as-a-platform-for-digitization.pdf (дата обращения: 30.05.2017).

20. Mendis D. Orphan Works. URL: http://www. Copyrightuser.org/topics/orphan-works/ (дата обращения: 30.05.2017).

21. Satoshi Nakamoto satoshin Bitcoin: a Peer-toPeer Electronic Cash System@gmx.com. URL: www.bitcoin.org//https://bitcoin.org/bitcoin.pdf (дата обращения: 30.05.2017).

22. Silver J. Blockchain or the Chaingang? Challenges, opportunities and hype: the music industry and blockchain technologies. URL: http://www.create.ac.uk/publications/blockchain -or-the-chaingang-challenges-opportunities-andhype-the-music-industry-and-blockchain-technologies/ (дата обращения: 30.05.2017).

23. Shinner $S$. Blockchain technology and IP. URL https://www.taylorwessing.com/download/artic le-blockchain-technologyand-ip.html (дата обращения: 30.05.2017).

24. Thompson $C$. The difference between a Private, Public \& Consortium Blockchain. A Simple Explanation for Dummies. URL: http://www.blockchaindailynews.com/The-difference-between-a-Private-Public-ConsortiumBlockchain_a24681.html (дата обращения: 30.05.2017).

25. Toves J.A., Hickey T. B. Parsing and Matching Dates in VIAF. URL: http://journal. code4lib.org/articles/9607 (дата обращения: 01.06.2017). 